\title{
リウマチ性心疾患に打けるタンニン酸赤血球凝集反応 による溶連菌型特異抗体の研究
}

\section{第 1 編 基礎的検討}

\author{
東京大学医学部附属病院分院内科教空（主任小林太刀夫教授） \\ 西 村接夫
}

\section{STUDIES ON STREPTOCOCCAL TYPE-SPECIFIC ANTI M ANTIBODIES IN RHEUMATIC HEART DISEASE USING TANNIC ACID HEMAGGLUTINATION. (1) FUNDAMENTAL STUDIES}

Toshio NishImURA

Department of Internal Medicine, Branch Hospital University of Tokyo

(Prof. Tachio Kobayashi)

\begin{abstract}
概要 リウアチ性心突患已溶連菌感染加密接规因果関係にあることは，各方面より奉証されているが，

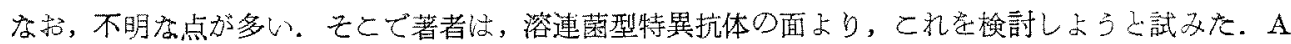
群 溶連菌は感染防禦に関与するといわ机る蛋白質性のM抗原已呼ばれる型特異的な物質によつて分 類さ妃ている．したがつて，M抗原に基づく菌型の分類は，人体の溶連菌感染症に括ける免疫，ひ心

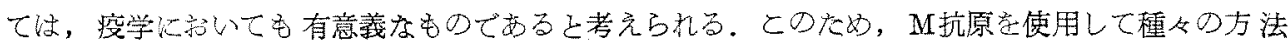

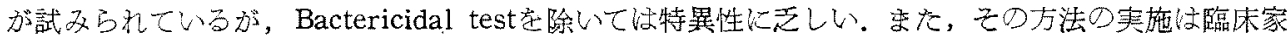
にとつて，必ずしも容易でない，ととに扔いて，著者法Boydenの感作タンニン酸赤血球凝集反応の 改良法 (熊谷) 在, 初幼て溶連菌感染定に応用し, 菌液による吸収試験, 抗原液による抑制反応, Bactericidal test との比較，抗原のトリプシン処置等種ミの方法で型特異性老証明し，本法が患者血 清中の型特異抗体の研究に用いうるとと示した。
\end{abstract}

\section{I. 緒 言}

リウマチ性心疾患と溶連菌感染加密接な因果関 係有することは，各媔より箺証されている。 しかし，な挍，不明な点加多い，そこで著者妁，

本論文は第23回日本血液学会総会（昭和36年 4 月 9 日)，第 5 回日本りウーキ協会総会（昭和 36 年 5 月)，第35回日本伝哚病学会総会 (昭和36年 7 月)，第 23回日本循環器学会関東甲信越地方会稳会（昭和36 年12月9日), 第59回日本内科学会 (昭和37年 4 月),

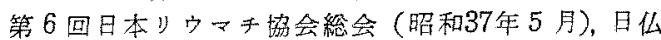
国際ゼミナール（昭和37年11月），モントリオールに 小ける第 8 回国際微生物学会（1962年8月）（追加 討諭）に一部発表した。
溶連菌型特異抗体の面よりこれを椮討しようと 試みた，連鑜球菌，な汃んずく，A群及溶連菌は 人体感染と密接な関係有し，その抗原棈造は詳 しく調べられている。す存わち，蛋白賴性のM抗 原と呼ばれる型特異的な物質によつて, Lancefield ${ }^{1} ら は ， A$ 群菌を 1 型から51型まで分類して いる.

このM抗原は感染防徱に関与するものであると され，人体の感染症に拈け负疫，ひいては，溶 連菌感染症の疫学もこの菌型ををとにして考え ることができる。したがつて，人体感染症に扮い て，溶連菌型特異抗体を究明することは極如て必 
要である、このため，M抗原を使用して，マウス 防禦試験 ${ }^{2}$, 凝集反応 ${ }^{33}$, 沈降反応 ${ }^{4}$ などが試みら れているが, 抗原の多様性, 非特異的反応の存 在, 動物契験と患者血清における結果の不一致, 各菌型間の交叉反応の多いことなどのため，実際 的意義が薄い。現在, 最も信賴されているのは,

Bactericidal test5うであるが，この方法は特殊な 操作を必要とし，臨床家にとつては，その実施は 容易でない。

こ〉に著者は，教室の熊谷 ${ }^{6} の$ 行なつたBoyden7)の感作タンニン酸赤血球凝集反応の改良法の 応用を試みた。すなわち、 $\mathrm{A}$ 群 $\beta$ 溶連菌を培養し，

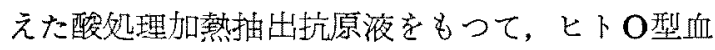
球学感作し，感作タンニン酸赤血球凝集反応を試 みたところ，ウサギの免疫血清において，高い特 異性が認められた。ついで，患者血清に応用し， 抗原による抑制反応，菌液に上る吸收試験， $\mathrm{Ba}$ ctericidal testとの比較, 抗原のトリプシン処置 等を行ない,その型特異性を証明しえた。さらに， 臨床的に多数例について検討し，本法が溶連菌感 染症における型特暴抗体の検出法として，臨床的 に用いうるすぐれた方法であることを認めたの で，こ〉に報告する，第 1 編において，基礎的検 討の結果について还へ，第 2 縓において，臨床的 㭘討，特に、リウマチ性心疾患について検討した 結果学報告する。

\section{II. 実験材料および実験方法}

\section{(I) 材 料}

a) 緩衝食塩水：生食水と等容量 の所要のpH （通常 7.2）のS $\phi$ rensen燐酸塩緩衙液を混じて作 製した。

b）赤血球： 七ト O型赤血球は10\%，ウサギ の赤血球は $3.8 \%$ クエン酸ソーダを用いて, 実 験当日採血し，直ちに使用した，前日採血のもの は氷公に保存しても，つぎの異好性抗体吸收には 使用しえたが，感作タンニン酸赤血球には不適で あつた。

c）タンニン酸：本邦製（Shuzui社）を用い た。必ず実験当日，上記の緩衝食塩水を用いて新
群な希釈法を作つた（通常PH $7.2 ， 2 \times 10^{4}$ 倍を 使用).

d）血清希釈液： 正常なウサギの血清を $56^{\circ} \mathrm{C}$ 30分で不活化し，ヒトO型血球で異好性杭体を吸 収したのち，塋化ソーダを $0.1 \%$ 制に加えて， $-20^{\circ} \mathrm{C}$ に保存し，用に臨みとかし，緩衝食壏水で 100倍に希採して，血清希釈液として用いた。こ の血清希釉液は，必ず実験当日作製のもののみを 使用した。

e）感作タンニン酸血球㠜集反㲿用抗原

(i) 培地の作製

表1のごとく行なつたすすなわち，ます，Todd-Hewitt培地 ${ }^{8) 9}$ を作製した。脂肪をよく取除 いた馬肉を細挫し，この $500 \mathrm{~g} に$ 蒸留水 $1 l$ 加 え，一夜水室に保存し，柆日徐々に加温して温度

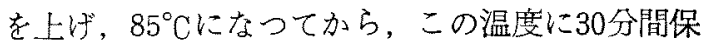
つて後, 温度を下げ滤紙で渚過する。この肉水 1 にたたいて，ネオペプトン（Difco）20gを加 え加温溶解させる。 つぎに, $1 \mathrm{NONaOH}$ 夜で $\mathrm{pH}$ を6.8〜 7.0に上げこれに，

$$
\mathrm{NaCl} 2.0 \mathrm{~g}
$$

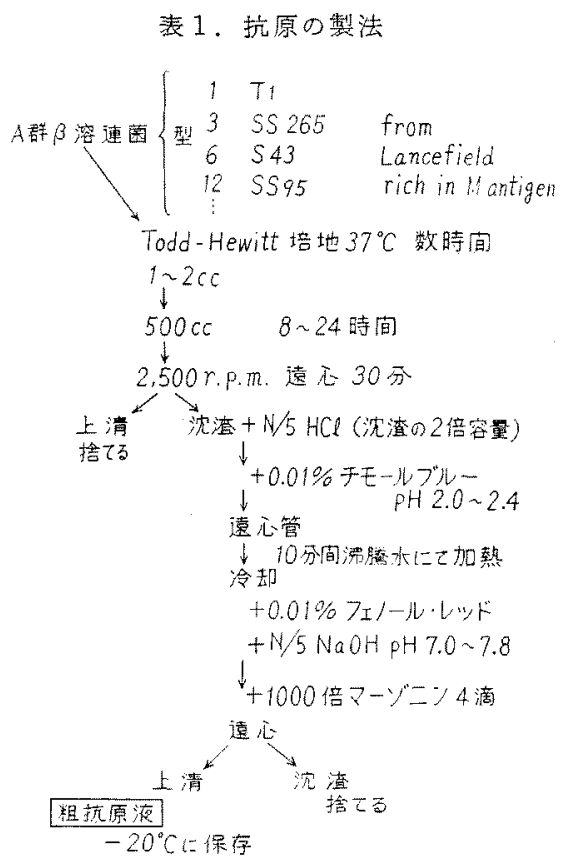


表2。使用した菌株

\begin{tabular}{|c|c|c|c|c|c|}
\hline $\begin{array}{l}\text { 菌 } \\
\text { 型 }\end{array}$ & 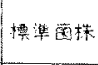 & $\begin{array}{l}\text { 荞 } \\
\text { 型 }\end{array}$ & 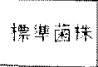 & 䍘 & 摽染茵株 \\
\hline 1 & II 型 & 18 & $I 17 \mathrm{C}$ & 35 & 0171 \\
\hline 2 & $T 2$ & 19 & I 170 & 36 & $C 119$ \\
\hline 3 & SS 265 & 22 & $T 22$ & 37 & C242 \\
\hline 4 & T4 & 23 & I 23 & 38 & $C 141$ \\
\hline 5 & T5B & 24 & $C 98$ & 39 & $C 95$ \\
\hline 6 & $S 43$ & 25 & $83460 \mathrm{P}$ & 40 & $C 143$ \\
\hline 8 & 0365 & 26 & $I 17 \mathrm{~F}$ & 41 & $\mathrm{ClOl}$ \\
\hline 9 & T9 & 27 & T27 & 42 & $\mathrm{Cl13}$ \\
\hline 10 & El4 & 28 & 728 & 43 & $C / 26$ \\
\hline 11 & THI & 1.9 & 023 & 44 & $\mathrm{Cs12}$ \\
\hline 12 & 5595 & 30 & D 24 & 46 & $C 105$ \\
\hline 13 & $T / 3$ & 31 & $\mathrm{~J} 137$ & 47 & 0744 \\
\hline 14 & 523 & 32 & $5 S 48$ & & \\
\hline 15 & $T / 5$ & 33 & $C 107$ & & \\
\hline 17 & $J 17 E$ & 34 & $C 142$ & & \\
\hline
\end{tabular}

$\begin{array}{ll}\mathrm{NaHCO}_{3} & 2.0 \mathrm{~g} \\ \mathrm{Na}_{2} \mathrm{HPO}_{4} \cdot 2 \mathrm{H}_{2} \mathrm{O} & 0.5 \mathrm{~g} \\ \text { ブドウ糖 } & 2.0 \mathrm{~g}\end{array}$

を次アに加え，直下で加熱する．次に，冷却して $\mathrm{pH}$ 再じ測定する。通常は 8.0〜8.2になつてい る。こ机滤紙で滤過し，適当な容器に分注し， $100^{\circ} \mathrm{C}, 20$ 分〜 30分ずつ 3 日間, 間久隇菌する. 作製後，できるだけ早く使用した。

(ii）酸処理加熱抽出抗原液の作製(116)

あらかじめ 1〜2ccのTodd-Hewitt培地に菌 （表2に示した42種でLancefieldょり伝研および 北里研究所に送付されたものから分与されたもの である。）を移植し, 数時間, $37^{\circ} \mathrm{C}$ に培養し, 菌㤎 発育してきたら，これを全部 $500 \mathrm{cc} の$ 同培地に移 し， $37^{\circ} \mathrm{C}$ R 24時間培養し，2500rpm30分間遠 心沈殿して上清を捨てる，沈殿した菌体に 2 倍容 量の $1 / 5 \mathrm{~N}-\mathrm{HCl}$ 夜（生食水で作る）を加え，菌体を 白金耳で注ぐし，一様な浮遊液とし，0.01\%チモ 一ルプル一液を 1 滴加え, $\mathrm{pH}$ が 2.0 2.4である ことを確かめる。このスピッツ遠心管を沸腾水中 で10分間， 2〜3分置きによく摫䢁しながら加蓺 し，专の後直ちに椧却する。次に，0.01\%フェノ 一ルレッド液を 1 滴加え, $1 / 5 \mathrm{~N}-\mathrm{NaOH}$ 液（蒸留 水で作る)を毛細管ピペットで滴下し， $\mathrm{pH} 7.0$ 7.8 程度にする。 さらに，必要に応じてN/20の $\mathrm{HCl}$ 液，または，NaOH液で細いpHの修正を行な
う。これに1000倍マーゾニン液 4 滴を加えてか ら，遠心沈殿して，透明な上清をとり，感作タン ニン酸赤血球凝集反応用の抗原とする.これを $-20^{\circ} \mathrm{C}$ のアイスポックスに保存し，沈殿が生じた 場合は，pHを修正し遠心して使用する。

(f) 吸收試験用菌液の作製

上記の万法で菌を培盖し，その菌液を2500rpm 30分間遠心沈殿して上清を捨て，生食水で10\%菌 液を作り $56^{\circ} \mathrm{C} 30$ 分で堿菌する。

（g）群決定のための血清

予研草閏氏並びに駒込病院小林健三民上り分与 された群血清を使用した。

(h) A 群型血清

表1に示した菌株にたいするそれぞれのウサギ の抗血清で，これは，草間氏並びに，小林氏の好 意により分与されたものを使用した。

(i) 患者血清

本学分院内科の入院および外来のリウマチ熱, リウマチ性心疾患, リウマチ㥞関節炎，その他の 患者方よび駒込病院入院の猩紅熱患者の时静脈よ り埰血し，血清を分離後， $56^{\circ} \mathrm{C} 30$ 分で不活化し - $20^{\circ} \mathrm{C}$ のイスボックスに保存し，用に臨み融解

して終檤測定した。

（II）実験方法

（1）感作タンニン酸赤血球凝集区応の術式 6 )

a）赤血球のタンニン酸処置

3 回洗つた沈査血球 1 容量に対し， pH 7.2緩衝 食塩水 2 容量, 25 倍タンニン酸溶液 3 容量を加 え，上く混じ室温に10分間保存し，1回緩衝食塩 水を用いて，弱い力で遠心し，その沈渣をタンニ ン酸(処置)血球として，次の操作を行なつた。

b）タンニン酸血球の抗原感作

タンニン酸血球の沈渣 1 容量にたいし，緩衝食 塩水 2 容量および後述の適当の濃度の抗原液 3 容 量を加え，よく混じ $37^{\circ} \mathrm{C} 30$ 分保存し，約10倍量の 上記の血清希积液を用いて，弱、遠心力で 2 回洗 い，残存抗原を充分除去した後，20倍容量の血清 希釈液を加えて，5\%感作血球液を作製した。別 
に対照として，タンニン酸処置のみの血球の $5 \%$ 血球液を作製した。

c）血球凝集反応の術式

ビールス血球凝集盤法（平沢製作所製80コおよ び 144コの山面を有するプラスチックの平盤）を 用いた。今 4 種の抗原，たとえば， $1 ， 3 ， 6$ ， 12，46型を用いた場合には，上記の血球希釈液を もつて，ウサギの免疫抗血清あるいは，患者血 清の倍数希积列(通常 $1: 12$ 上り始め，1：6,144 に至る各管 $0.2 \mathrm{ml}$ ずつ） 6 列作り，縱に，上 上り，1，3，6，12，46各型のA群 $\beta$ 溶連菌の 酸処理加熱抽出抗原液をもつて感作したタンニン 酸処置ヒト $\mathrm{O}$ 型血球液を, 最後の列には, 対䐋 として，抗原を感作しない $5 \%$ タンニン酸血球

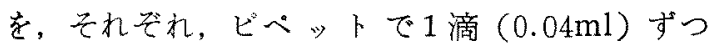
加え, よく湜じた後, 室温に 2 時間静置して制読 し,さらに, 一夜静置 (夏期は水室) して結果を 確かわた，管底像を肉眼で観察して血球が底面に 一様に散在しているのを陽性，まるく中央に集ま つているのを陰性，蛇の目模様を呈しているもの を(土)とした。

(2) 吸収試験の術式

$A$ 群 $\beta$ 溶連菌を酸処理加熱抽出抗原液の作製の 項で述べたと同様な方法で培養し，3000rpm30分 遠心し，沈殿した菌体を生食水で 2 回洗い，それ に生食水を加えて10倍の㴓浊液とする。これを

\begin{tabular}{|c|c|c|c|c|c|c|c|c|c|c|c|c|}
\hline tons & 1: 50 & 00 & & & & & & $m$ & 20 & 12500 & 200 & $C_{1}$ \\
\hline $1: 30$ & - & - & - & - & $1-$ & + & + & + & + & + & + & \\
\hline 60 & & - & - & 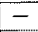 & - & \pm & + & + & + & & 3 & 1 \\
\hline & & & $\therefore$ & - & - & - & \pm & + & + & + & + & t \\
\hline & & - & - & - & - & - & - & + & + & + & & 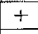 \\
\hline & & - & - & $1-$ & - & - & - & - & + & 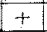 & & + \\
\hline 860 & & - & - & - & - & - & $=$ & - & - & \pm & & \\
\hline $1: 1920$ & & & - & - & - & - & - & - & - & - & - & + \\
\hline $1: 3840$ & & - & - & - & - & - & - & - & - & - & - & $=$ \\
\hline $1: 7680$ & & & - & - & - & - & - & - & - & - & - & $=$ \\
\hline 15360 & & - & - & - & - & - & - & $=$ & - & - & - & - \\
\hline $1: 30720$ & & 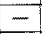 & - & - & - & - & - & - & - & - & - & - \\
\hline 1 & $=$ & - & - & - & $=$ & - & - & - & - & $1-$ & - & 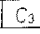 \\
\hline
\end{tabular}

$56^{\circ} \mathrm{C} 30$ 分で隇菌する. 冷却した後， 1 万分の 1 の 割合にマーゾニンを加え, $-20^{\circ} \mathrm{C}$ のイスボック

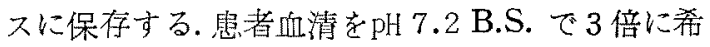
积し，それに10倍菌液を固量加えて6 倍の䌽浊液 とする.これを $37^{\circ} \mathrm{C}$ の恒温槽に 1 時間入れ，その 間，ときとき振つてよく混合する。杂れを3000 rpm30分間遠心し，上清を毛細管ピペットで菌体 の混じないよう静かに昅引する. 対照として，3 倍血清に，生食水を同量加えたものを $37^{\circ} \mathrm{C} 1$ 時間 恒温槽に入れる，加くのごとく，同一血清を少な くとも二つ以上の型の菌液で吸收したものについ て反応を試みた。

（3）抑制区応の術式（写真 1)

横に，感作抗原の倍数希勫列を，縱に，ウサギ の抗血清，または，患者血清の倍数希积列を作 り，同量ずつ加えて区応の場を画き，よく混和し て公温に30分間放置後，これに感作血球を加えて 血球凝集反応を行なわせ，抗原による抑制反応の 場定観察した。

(4) 抗原のトリプシン処置法

トリプシンは本邦（持田製薬）製の結晶トリプ シン製剤で，アンプルに封入したものを用いた。

$$
1.50 \text { 抗原 (type } 3 \text { ) } \longrightarrow
$$
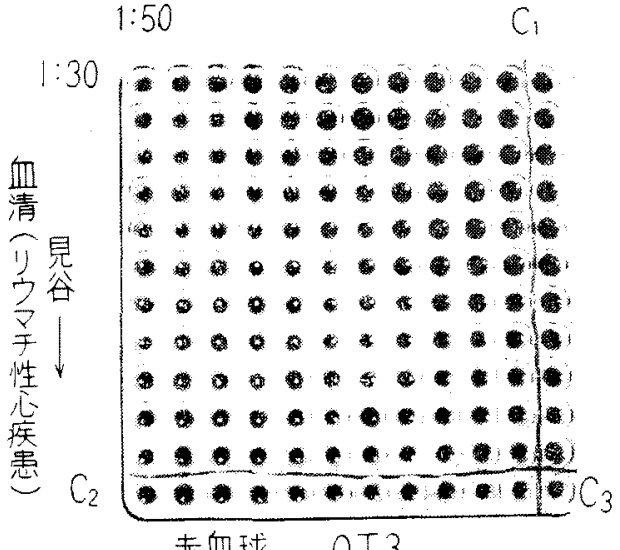

赤血球 OT3

写真 1 。抑制反応の場

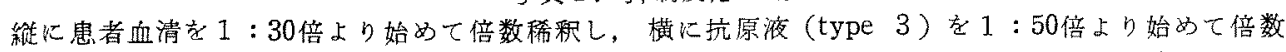

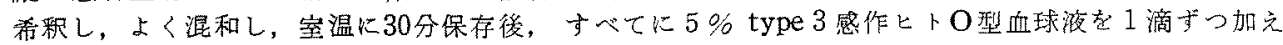
て，2 時間後に判定した。左はその判定の結果である。

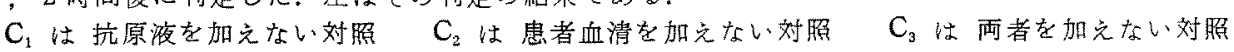


$5 \mathrm{cc}$ の溶解液にトリプシン $1 \mathrm{~A}(10,000$ 單位 $)$ すな わち，1ccに2,000單位になるように溶解し，50倍

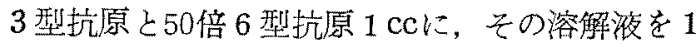
Ccずつ加え，室温（約 $23^{\circ} \mathrm{C}$ ）に10分間放置する. これを感作抗原として，血球㠜集反広を試みた。

（5）溶連菌の咽頭よりの分離方法

内山ら 103 の希䣋培盖法によつて, 純培養を行な い，Gram染色によつて鏡娭確認のうえ，一白金 耳は保存培地に培養, 残りは, 50mlのTodd-Hewitt培地に移植し，沈降抗原华製に用いた。

（6）沈降抗原作製方法

Lancefield $^{1}$, Swift弓の塩酸抽出法の変法を用 いた. 感作タンニン酸血球凝集反応に用いる感作 抗原の製法とは別に，駒込病院で行なつている方 法を用いた11)。すなわち，Todd-Hewitt培地に37 C，18～24時間培養せるものを所定の目盛付遠心 沈殿管に採り，3000 rpm30分間遠沈し，上清を捁 て，えた菌体に20倍量の $N / 20$ 塩酸食塩液(生食水 に，1 N塩酸を $1 / 20$ の割に加える）を加え，充分 に混和し，沸騰水中に入れて，ときぼき振盪しな がら15分間置き流水にて冷却の後， $0.1 \%$ エ ールレッド夜 1 滴加え, 苛性ソーダ液をもつて $\mathrm{pH}$ 7.0に補正する. 次いで, 3000rpm30分閒遠沈 し，透明な上清をとり出し，4 分の 1 の割合にマ ーゾニンを加え，氷窒に保存して沈降抗原とす ๖.

（7）溶連菌群血清の作製方法

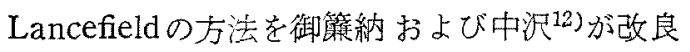
して，溶連菌をクロームワクチンとして作製した もの学使用した。

（8）溶連菌型血清

Conroy and Updyke ${ }^{13}$ の方法に準じて，小林 健三氏の作製したものの分与を受けた。一部，草 間氏作製のものも含まれる。すな⿰力, 表 1 に示 すごとく，34種の型血清である。

（9）沈降反応術式

Lancefield ${ }^{14)} の$ 毛細管重層法を用いた。

\section{(10）ASL-O測定法}

診断用ストレプトリジンO “北研”を用いた。 測定法はRanzおよびRandal115)法を用いたが，赤 血筀浮遊液は伝研法の $2 \%$ 用いた。

\section{（11）C R P測定法}

大部分の症例は本学分院細菌検查室で㭘查した が，一部分は，著者が本邦製 (㙝和葙品) の抗 RP血清を用い，術式は，その使用書のごとく行 なつた。

（12）Rose反応の方法

i) ヒツジ血球は市販のものを用いた。

ii）患者血清は5 $56^{\circ} \mathrm{C} 30$ 分で不活化した。

iii)感作血球注凝集価 1 ：4000倍のものを使用 し，血球濃度は $1 \%$ 用いた。

iv）不活化した患者血清を，1：8倍より2倍 連続希釈法にしたがつて希釈し，その同じもの2 列について凝集反応を行ない，0.100ずつ血球を 加えた。

v） $37^{\circ} \mathrm{C}$ ゆぶ衫に2 時間（その間15分ごとに よく振る),さらに, 水室に 1 晚故置した。

vi）水室からとり出して, 直ちに凝集の有無を 肉眼的にしらべ、1十の凝集を示した最高希䣋倍 数をもつて，その血清の凝集価とした。

vii） Diff. T.16以上のとき陽性とした。

(13) RA testの方法

Hyland製RA test用試楽を用いた. glycinesaline buffer希勫液 $1 \mathrm{cc}$ に患者血清0.05cc加えて 20倍に希秋する。これをスライドの上に 1 滴落 し, Latex-Globuline試薬の 1 滴を加え，つまよ うじで的 $20 \times 25 \mathrm{~mm}$ に拡げる。この前に，対照とし て陽性および陰性のコントロール血清に試薬を 1 滴ず加え，反応を確加めておく，反庍の制定は 1 分後, 肉眼で観察した。

(14) F II testの方法

熊谷の方法6る用いた。

\section{III. 実験成績}

（1） 反応の型特異性についての桱討

a) 家舫の抗血清についての証明

抗原 $1 ， 3 ， 6 ， 12$ 型之家鬼抗血清抗 1，3， 
表 3 . 抗血清抗原の特異性の检討（家鬼）
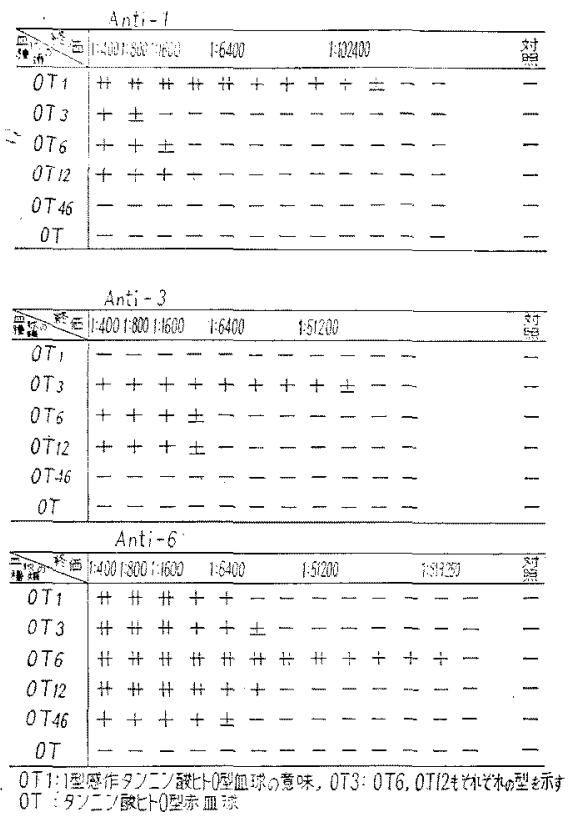

表 4、抗血清抗原の特異性の检討（家東）

\begin{tabular}{|c|c|c|}
\hline \multicolumn{2}{|c|}{ 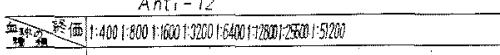 } & \\
\hline OT1 & $+++ \pm-\cdots-\cdots-$ & \\
\hline $0 . T 3$ & $+++ \pm----\cdots-$ & \\
\hline OT6 & $H++ \pm+-\cdots-\cdots$ & - \\
\hline OT 12 & $H+H+++++-\cdots$ & . \\
\hline OT46 & $+ \pm \pm-\cdots-\cdots-\cdots$ & \\
\hline$O T$ & $1-\cdots-\cdots-\cdots$ & \\
\hline
\end{tabular}

6，12型について，本法を試みたところ，表 3 ， 4 に示すごとく，抗 1 型血清は102,400倍の終洒 を有し，他の終価と5 管以上の差，抗 3 血清は 51,200 倍で 5 管以上の差, 抗 6 血清は819,250 倍 で 6 管以上の差，抗12血清は 51,200 倍で他の終 価と 4 管以上の差を示し，明らかに型特異性が認 められた。

b) Bactericidal testにより 型特異抗体を証明 された患者血清についての检討

Bactericidal testで， 6 型抗体を有することを 確かめられたリウマチ様関節炎の患者血清に，本 法を試みた結果, 表 5 に示すごとく，6型抗原に たいして 6,144 倍の終価を示したのに，他の抗原 では192倍以下であつた。
表 5. Bactericidal test との比較

(6型梌出の血清について)

鬼老草

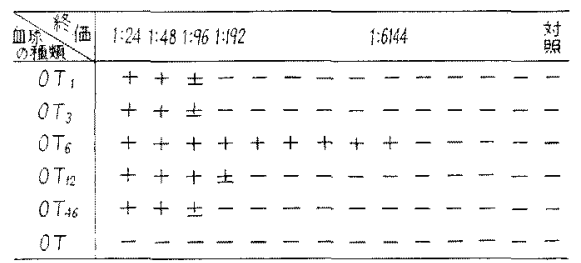

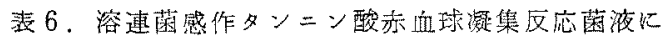

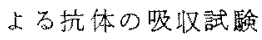

\begin{tabular}{|c|c|c|c|c|c|}
\hline 要要 & 6 & 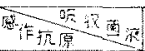 & 住境 & Type 3 & Type 6 \\
\hline \multirow{6}{*}{ 草 } & \multirow{6}{*}{ 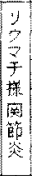 } & Type 1 & 0 & 0 & 0 \\
\hline & & 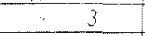 & 0 & 0 & 0 \\
\hline & & 6 & $1: 1536$ & $1: 1536$ & 0 \\
\hline & & 2 & $1: 24$ & 0 & 0 \\
\hline & & 46 & $1: 24$ & 0 & 0 \\
\hline & & $9 \%=0$ & 0 & 0 & 0 \\
\hline \multirow{5}{*}{ 晃 } & 3 & Type 1 & $\therefore: 40$ & $7: 20$ & $1: 20$ \\
\hline & $\vec{z}$ & 3 & $1: 2560$ & 0 & $1: 2560$ \\
\hline & 委 & 6 & $1: 640$ & $1: 640$ & 0 \\
\hline & 案 & $\because \quad 12$ & $1: 320$ & $1: 160$ & $1: 320$ \\
\hline & 䈏 & 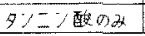 & 0 & 0 & 0 \\
\hline
\end{tabular}

c）菌液の吸收試騕による証明

表 6 に示すごとく，抗体は感作抗原と同型の菌 液によつてのみ完全に吸收されている。すなわ ち，表において，上の鬹のリウマチ様関節炎の患 者血清は， 6 型感作の赤血球に対し，1,536 倍と いう高い終価を有するが，3型の菌液では全く吸 収されず，食塩水による吸収と同様であり，6型 の菌液では完全に吸收されている。下の欄のリウ マチ性心疾患の患者血清は，3型抗原感作血球に 対し， 1 : 2560倍という高い終価を有するが,こ の抗体は 3 型の菌液で完全に吸收され，6型の囷 夜では食塩水による吸收上全く同じ值を示してい る。すなるう，患者血清について型特異性が証明 された。

d）抑制反応に上る証明

表 7 おび写貪 1 のごとく，反応は，加えた抗 原抗体の濃度に注ぶ比例して抑制され，本反応の 抗体は赤血球に败着されている抗原に刘するもの であるこ亦証明されている。な招，他の型の抗 原では全く抑制が認められず，抑制反応によつて も型特異性が証明された。 
婊 7 。溶速菌感作タンニン酸浾血球凝箱区応の感作 抗原による抑制反応

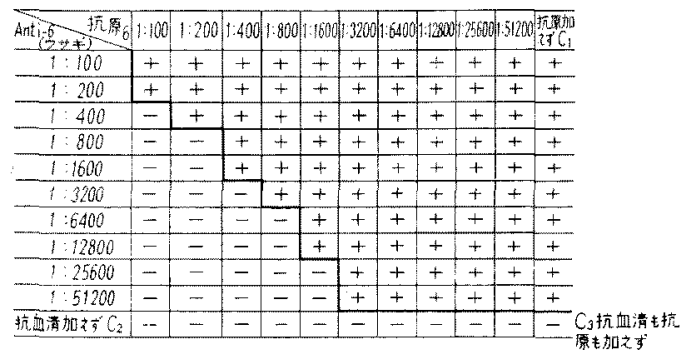

表 8. 备種の抗原飞与る抑制反応 $\left(\mathrm{OT}_{3}\right.$ にいて

患者：見○静○( 3 型飞高い終洒有士る血清)

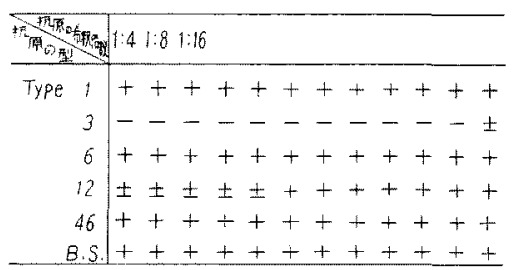

次に，同型および異型の抗原による抑制によ

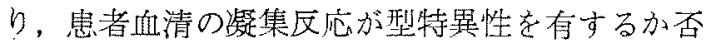
かをみるテストを行なつた。横に，各抗原の原液 を倍数希积し，各管に同量の患者血清を加えた。 表 8 に示すごとく，3型の高い抗体価を有する患 者血清の 3 型感作血球による凝集区応は，3型抗 原によつてのみ完全に抑制され，他の型の抗原液 によつては全く抑制されていない。れによって も，型特異性が証明された。

e) B, C, G群溶連菌抗原による凝集区応 表 9 のことく、A群以外に，B，C, G群溶連菌よ 表 9、A, B, C, G 群溶連菌抗原感作タンニン酸赤血

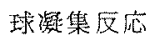

\begin{tabular}{|c|c|c|c|c|c|c|c|c|c|c|c|}
\hline (A) & 漟 & 绮何 & 140 & 石O & 40 & 港口 & 鬲O & 1.0 & 松O & 70 & 㰮。 \\
\hline & 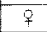 & $\hat{\theta}$ & 9 & q & 9 & 9 & $\overline{9}$ & 9 & ? & 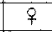 & 9 \\
\hline & 35 & 17 & 35 & 9 & 12 & 18 & 20 & 40 & 21 & 24 & 18 \\
\hline 琮 & 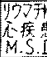 & S. & 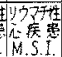 & 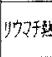 & 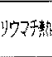 & 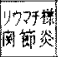 & 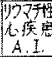 & 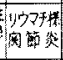 & 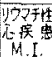 & 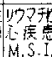 & 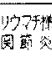 \\
\hline $\begin{array}{c}\left.T_{A}\right) \\
\left(T_{Y y p e}\right)\end{array}$ & $11: 384$ & $1: 190$ & $1: 768$ & $1: 1526$ & $1: 48$ & $1: 768$ & $1: 768$ & 17768 & $1: 48$ & $1: 24$ & 1,768 \\
\hline$O T_{B}$ & 0 & 0 & 0 & 0 & 0 & 0 & 0 & 0 & 0 & 0 & 0 \\
\hline OTC & 0 & 0 & 0 & 0 & 0 & 0 & 0 & 0 & 0 & 0 & 0 \\
\hline$O_{G}$ & 0 & 0 & 0 & 0 & 0 & 0 & 0 & 0 & $y$ & 0 & 0 \\
\hline OT & 0 & 0 & 0 & 0 & 0 & 0 & 0 & 0 & 0 & 0 & 0 \\
\hline SL-0 & 333 & 333 & 833 & 833 & 833 & 333 & 50 & 100 & 125 & 125 & 333 \\
\hline
\end{tabular}

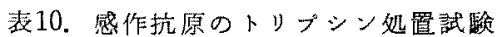

\begin{tabular}{|c|c|c|c|}
\hline 筩告 & 見舶○ & 深。仁， & 佐口道。 \\
\hline 胜 & 9 & 7 & $\delta$ \\
\hline (1) & $35 才$ & $20 t$ & $17 \pi$ \\
\hline & 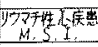 & 急性肾终 & 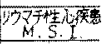 \\
\hline $\mathrm{OT}_{3}$ & $1: 2560$ & $1: 80$ & $1: 2560$ \\
\hline $0 \mathrm{~T}_{6}$ & $1: 640$ & $1: 640$ & $1: 20$ \\
\hline OT $T_{3}$ Typsin & 0 & 0 & 0 \\
\hline OT6 Trypsin & 0 & 0 & 0 \\
\hline$O T$ & 0 & 0 & 0 \\
\hline
\end{tabular}

りも酸抽出抗原を作製し，リウマチ性心疾患の患 者血清について检討したが，3群とも，凝集反応 を全く認めなかつた。本反応の感作抗原 $\mathrm{M}$ proteinが, $\mathrm{B}, \mathrm{C}, \mathrm{G}$ 群の溶連菌に含まれていないこと 加ら，当然のことと思われる。

f)トリプシン処置試験

表10に示すごとく，3 型および 6 型感作抗原の トリプシン処置試験を行なつた結果，両者とも終 価が0であつた。これは型特異抗原がトリブシン により破壞されるという従来の知見とよく一致す るものであり，本反応が型特異抗原 $\mathrm{M}$ proteinに よるものであることを訨明するものと思われる。

g）咽頭培養朲出菌と血清型特異抗体の一致

抗生剂を全く投与しなかつた猩紅熱患者の咽頭 培養菌型と血清中の型特異抗体を調べた結果，表 11のごとく，咽頭培養検出菌も，血清中の型特異 抗体も 6 型で，その一致することを認め，本法の 型特異性を，さらに確かるることができた。ま

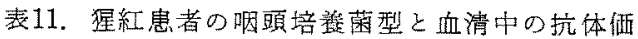
患者：関○房 $\bigcirc ， 11$ 才, 女。

\begin{tabular}{|c|c|c|c|c|c|}
\hline 䖽寔白 & 23 - 血 & $30 / \pi$ & $5 / \pi$ & $21 / v$ & $18 / 81$ \\
\hline 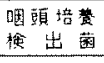 & 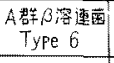 & Type 6 & Type 6 & Type 6 & 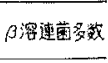 \\
\hline$A S L-0$ & 250 & 500 & 500 & 333 & 333 \\
\hline $\begin{array}{l}\text { 型特買 } \\
\text { 㧧 }\end{array}$ & 0 & 0 & 0 & $\begin{array}{c}\text { Type } 6 \\
1: 12 \\
\end{array}$ & $\begin{array}{c}\text { Type } 6 \\
1: 192 \\
\end{array}$ \\
\hline 病 & $3 日$ & 108 & 15日 & 59 日 & 878 \\
\hline 治 湶 & \multicolumn{5}{|c|}{ 抗生剖使用世 } \\
\hline
\end{tabular}


表12. 再現性の檢討

\begin{tabular}{c|c}
\hline-16 \\
\hline 1 管の荎 & 14 \\
\hline 2管以上の差 & 0 \\
\hline 合 㖕 & 30 \\
\hline
\end{tabular}

た，経過を追つて检討するに，型特異抗体はA S L-O值よりも遅れて上昇することが諗められ， Bactericidal testによるLancefieldら ${ }^{16)} の$ 知見と よく一致する成績であつた.

(2) 再現性の検討

1，3，6，12，30の5 型を用い， 6 個の血清 について30回再現性を検討し，婊12のごとく、一 致したものが16回，1管の差は14回，2管以上の 差はなかつた。したがつて，本法の再現性は充分 信賴できる成績であつた。

（3）交攴反応の検討

㒸星紅熱患者では，入院時之退院後を比較し，後

表13，交叉反応の検尌（22名について）

（他の型の抗原で吸収娞，終価の著しく低下した回数）

\begin{tabular}{|c|c|c|}
\hline $\begin{array}{l}\text { 吸収前 } \\
\text { 心終価 }\end{array}$ & 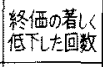 & 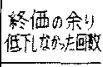 \\
\hline $1: 12$ & 1 & 0 \\
\hline $1: 20$ & 2 & 0 \\
\hline $1: 24$ & 12 & 2 \\
\hline $1: 40$ & 0 & 2 \\
\hline $1: 48$ & 5 & 1 \\
\hline $1: 80$ & 4 & 5 \\
\hline $1: 96$ & 4 & 4 \\
\hline $1: 160$ & 4 & 0 \\
\hline $1: 192$ & 7 & 2 \\
\hline $1: 320$ & 0 & 5 \\
\hline $1: 384$ & 0 & 4 \\
\hline $1: 640$ & 0 & 2 \\
\hline $1: 768$ & 0 & 3 \\
\hline $1: 800$ & 0 & 1 \\
\hline $1: 1536$ & 0 & 2 \\
\hline $1: 1600$ & 0 & 4 \\
\hline $1: 2560$ & 0 & 2 \\
\hline $1: 3072$ & 0 & 0 \\
\hline $1: 5120$ & 0 & 1 \\
\hline $1: 6144$ & 0 & 0 \\
\hline $1: 6400$ & 0 & 0 \\
\hline 合 計 & 39 & 40 \\
\hline
\end{tabular}

者において，型特異抗体の終侕が上昇していた。 これらには既往反応，あるいは，交弗反応もある と考えられたので，22名の㭧者血清について， $1 ， 3 ， 6 ， 10 ， 12 ， 18 ， 30 ， 37,40,460$ 各型 のそれぞれに充分な菌量を用いて吸收試験を行な つた，表13のごとく，他の型の抗原で吸收後，著 しい終価の低下したもの39件は，すべて 192倍以 下であり，320倍以上の24件は，いずれも著しい 終洒の低下は認められなかつた、したがつて， 384 倍以上を，有意の終価と見なし，192倍以上の 值を問題とするときは，かならず吸收試験を行な つた後，その型特異抗体か否かを考虑した。すな わち，吸収されるものは交文反応の可能性がある とみなした。

（4）多洒抗原液(polyvalent antigen)による 感作の検討

Lancefield の51型中42型の個々について，本 凝集反応を試みることは多くの時間を要する，よ つて,多価抗原液 (polyvalent antigen) による 感作を試みた。主な型 $1 ， 3 ， 6 ， 12 ， 46$ 型の組 合せと，稀な型13，14，15，17，19型の組合せに よる、それぞれ50倍に希釈せる多洒抗原液を作り， 凝集反応試み終価を單独抗原のそれと比較し た. 表14に示すごとく, 前者は， 3 型の終価が 3,072倍で最も高く，多洒抗原に上る終伍は，やは り，3，072 倍で一致した。後者は，どの型も終価 は0で多洒抗原による終価も0で一致を示した。

\section{表14. 多価抗原液 (polyvalent antigen)による 感作の終価}

\begin{tabular}{|c|c|c|c|c|c|c|}
\hline \multicolumn{3}{|c|}{ 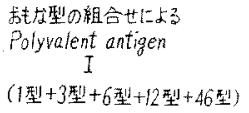 } & \multicolumn{4}{|c|}{$\begin{array}{l}\text { 帝な型o組合せたよるPolyvalent } \\
\text { antigen } \\
(13 \text { 型+14型+15型+17型+19型) }\end{array}$} \\
\hline 墨霓 & 見O争O & 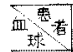 & 盟 & 泉 0 & 西 0. & 吉O \\
\hline OT: & $<1: 48$ & OT $_{13}$ & 0 & 0 & 0 & 0 \\
\hline$O T_{3}$ & $1: 3072$ & $O T_{14}$ & 0 & 0 & 0 & 0 \\
\hline OT 6 & $1: 96$ & OT15 & 0 & 0 & 0 & 0 \\
\hline $0 T_{12}$ & $1: 384$ & OT 17 & 0 & 0 & 0 & 0 \\
\hline$O T_{46}$ & $\angle 1: 48$ & $\Delta T_{19}$ & 0 & 0 & 0 & 0 \\
\hline $\begin{array}{c}\text { Polpratent } \\
I\end{array}$ & $1: 3072$ & $\begin{array}{c}\text { Polyvalent } \\
\text { II }\end{array}$ & 0 & 0 & 0 & 0 \\
\hline OT & 0 & OT & 0 & 0 & 0 & 0 \\
\hline
\end{tabular}


すなわち，多価抗原液による感作血球の終価は， その組合せ中の型の最高終価を示すと考えられ た。そこでわが国で検出されるA群及溶連菌の う，約40\%を占める11) といわれる $1 ， 3 ， 6 ，$ 10，12型の主な型汢もち万ん，比較的頻回に出現 する $18,30,37,40,44,46,5,23,29,39$, 41，42型については一つ一つ感作し，他の稀な型 は5 型ずつ組合せて多価抗原液を作り，感作を行 ない，毛し高い終価索有した組合せがあつた場合 には，その型の沶の扮のについて感作を行ない， 終価を決定した。

（5）抗原濃㛺の検討

a) 粗抗原の蛋白量測定

Lancefield らの51型中42型のA群及溶連菌の酸 加警抽出抗原の䨞白量を，ビューレット法により 测定した。粗抗原を同一のピペットで $0.2 \mathrm{cc}$ と り,ビューレット試薬 $5 \mathrm{cc}$ 加え, $25^{\circ} \mathrm{C} 30$ 分放置す る. その後, ADS比計の $540 \mathrm{~m} \mu$ フィルター で比色し，係数 0.0132 加汀る，蛋白量のg/dl が

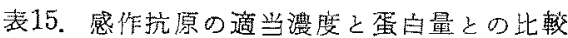

\begin{tabular}{|c|c|c|c|c|c|}
\hline 菌柇 & 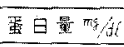 & 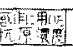 & 雷㚘 & 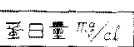 & \\
\hline 1 & 252 & 1.50 & 29 & 744 & 1200 \\
\hline 2 & 890 & $1: 50$ & 30 & 820 & $1: 100$ \\
\hline 3 & 173 & 1.50 & 31 & 650 & $1: 50$ \\
\hline 4 & 500 & $1: 50$ & 32 & 345 & $1: 50$ \\
\hline 5 & 850 & $1: 100$ & 33 & 1325 & $1: 50$ \\
\hline 6 & 340 & $1: 50$ & 34 & 901 & $1: 50$ \\
\hline 8 & 411 & $1: 50$ & 35 & 570 & $1: 50$ \\
\hline 9 & 265 & $1: 50$ & 36 & 516 & $1: 50$ \\
\hline 10 & 1486 & $1: 50$ & 37 & 637 & $1: 50$ \\
\hline 11 & 239 & 1.50 & 38 & 465 & $1: 50$ \\
\hline 12 & 292 & $1: 50$ & 39 & 570 & $1: 100$ \\
\hline 13 & 1260 & $1: 50$ & 40 & 491 & $1: 400$ \\
\hline 14 & 266 & $1: 50$ & 41 & 597 & $1: 400$ \\
\hline 15 & 106 & 1.50 & 42 & 385 & $1: 50$ \\
\hline 17 & 371 & 1.50 & 43 & 796 & $1: 50$ \\
\hline 18 & 820 & $1: 400$ & 44 & 980 & $1: 50$ \\
\hline 19 & 1030 & $1: 50$ & 46 & 199 & $1: 50$ \\
\hline 22 & 783 & $1: 50$ & 47 & 437 & $1: 50$ \\
\hline 23 & 704 & $1: 50$ & & & \\
\hline 24 & 450 & $1: 50$ & & & \\
\hline 25 & 863 & $1: 50$ & & & \\
\hline 26 & 624 & 1.50 & & & \\
\hline 27 & 770 & $1: 50$ & & & \\
\hline 28 & 1020 & $1: 50$ & & & \\
\hline
\end{tabular}

できる，その結果は表15のごとく，蛋白量と抗原 の感作力とは, 必括しも平行しなかつた。

b) 粗抗原の感作浀度の適当量の榆討 粗抗原を倍数希积し，各濃度でタンニン酸血球 を感作し，その終価を比較検討する，抗血清とし て家霓の抗血清走用いた（草間氏作製）。表16，17 のごとく，1，3，6，12型では，粗抗原の感作

表16。粗抗原の感作混度の適当量の検討

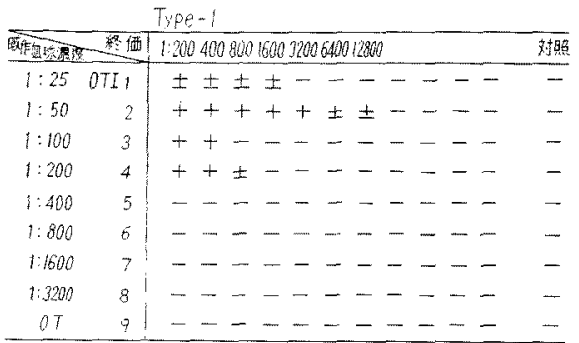

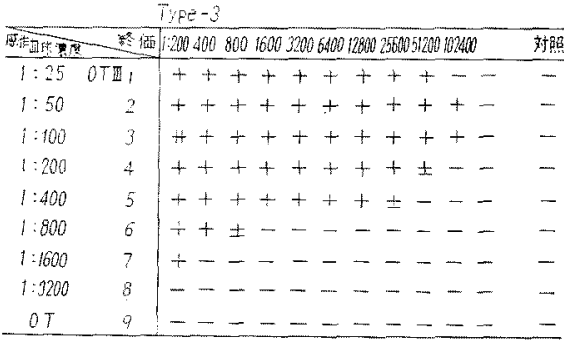

表17。粗抗原の感作漕度の適当量の検討

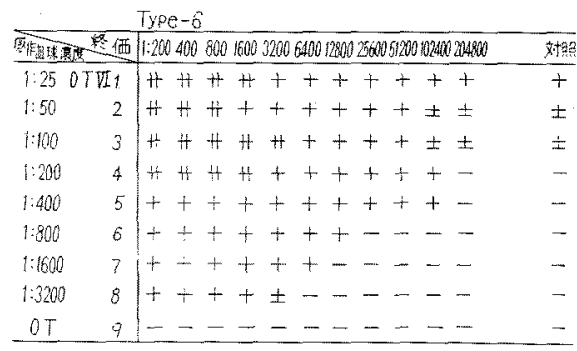

\begin{tabular}{|c|c|c|}
\hline 然1 & 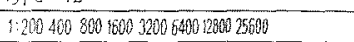 & 对能 \\
\hline 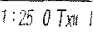 & $+++++++ \pm-\cdots$ & - \\
\hline 50 & $+++++++\ldots$ & - \\
\hline 109 & $+++++ \pm+\ldots--$ & - \\
\hline 2019 & $++++++-\ldots-\cdots$ & - \\
\hline 40 & $+++++ \pm--\cdots$ & - \\
\hline 803 & $+++--\ldots$ & - \\
\hline 1600 & $\pm--\cdots-\cdots$ & - \\
\hline 103200 & $-\cdots-\cdots-\cdots$ & - \\
\hline OT & $-\cdots-\cdots-\cdots$ & \\
\hline
\end{tabular}




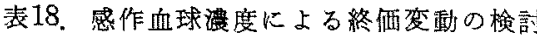
$\mathrm{OT}_{3} /$ Anti 3 劣用いる

\begin{tabular}{|c|c|c|c|}
\hline 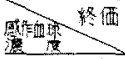 & 14009001603300600 & 89200 & fy \\
\hline $5 \% 3 \%$ & $4+t++\cdots--1$ & $---\cdots$ & - \\
\hline 2 & it $+4+t+t+t+$ & ---- & - \\
\hline $1 \%$ & $H+H++1+t+1$ & $\pm--\cdots$ & - \\
\hline $25 \% 2 \%$ & $+4++++1++1$ & $5---$ & - \\
\hline $1 \%$ & $++t+t+t+t$ & \pm---- & - \\
\hline $1.25 \% 2 \%$ & $t+t+t+t+t$ & \pm \pm--- & - \\
\hline $1 \%$ & $+t+t+t+t+$ & ++ \pm \pm \pm & \pm \\
\hline $0 T$ & $-m--\cdots-\cdots$ & $-\ldots--$ & - \\
\hline
\end{tabular}

濃度は 1 ：50倍が適当であつた。その他の型につ いては，家躳の抗血清不足のため患者血清につい て行ない, 粗抗原の感作濃度を一氾 $1 ： 50$ 倍にし て反店を試み，対盟の管底像が完全に中央に集 まるまで感作濃度を調節した。したがつて，型に よつては，1：400倍まで粗抗原を希䣋せねばな らなかつた。また，1：25倍以下の型はなく， 1：50㥉方ら 1：400倍の濃度方適当であつた。 したがつて，本反応を行なうにあたつては，終価 の高い患者血清を常に保存し対照にとり，抗原濃 度，あるいは，血球の感作力を調節する必要を認 めた。しかし、マーゾニンを入れてー20 $\mathrm{C} に$ 凍結 して保存した場合，粗抗原液の感作能力は約 1 年 間，ほとんど変化を譛めなかつた。

(6) 感作血球濃度の检討

3 型による感作血球と蒙愁の 3 型抗血清を用い た、表18に示すごとく，5\%1亂が最も終価が高 く，それ以下の濃度では終価が低く，それ以上の 漫度では終価が高かつた。したがつて，本区応に は常に $5 \% 1$ 滴の濃度で行なつた。

（7）10型と12型に対する検討

Watson \& Lancefield (1944) 17) はA群溶連菌 の10型と12型注同一抗原を有するため，M抗原に よつては，型分類されないが，T抗原が異なるた めここれよって二つの型，すなわち10型と12型 に型分類さ机ると述べている。この関係が本赤血 球凝集反応に上ればどうであるか子調べた。表19 に示すごとく，1：384倍以上の終洒を示した回 数45回中，完全に一致したものは15回で，1管の 差を有するものは18回，2管の差を有するものは 6 回で計39回，3管以上の差を示したものは 6 回
表19.10型と12型飞ついての检討（384倍以上の終 価见ついて)

\begin{tabular}{|c|c|}
\hline 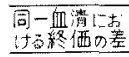 & 回 数 \\
\hline 一臸 & 15 \\
\hline 1 管筀 & 18 \\
\hline $2 "$ & 6 \\
\hline $3 "$ & 1 \\
\hline $4 \quad$ & 2 \\
\hline $5 "$ & 0 \\
\hline $6 "$ & 3 \\
\hline 7管以上刀美 & 0 \\
\hline 合 & 45 \\
\hline
\end{tabular}

表20１01型と12型について检討（384倍以上の終洒 にっいて) 12型と 1，3，6，10型の終価の 比整

\begin{tabular}{|c|c|c|c|c|}
\hline \multirow{2}{*}{ 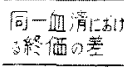 } & \multicolumn{2}{|c|}{ 可 } & \multicolumn{2}{|c|}{ 数 } \\
\hline & 1 型 & 3型 & 6 型 & 10型 \\
\hline 一致 & 3 & 7 & 5 & 15 \\
\hline |营力差 & 6 & 12 & 4 & 10 \\
\hline 2 & 10 & 3 & 6 & 3 \\
\hline 3 & 1 & 3 & 13 & 2 \\
\hline $4 "$ & 4 & 2 & 3 & 2 \\
\hline $5 \%$ & 0 & 1 & 2 & 0 \\
\hline $6 "$ & 6 & 4 & 10 & 2 \\
\hline 管以上麦 & 0 & 0 & 0 & 0 \\
\hline 枲 計 & 30 & 32 & 43 & 34 \\
\hline
\end{tabular}

あつた。しかし，同一血清において，1：384倍 以上の12型と $1 ， 3 ， 6 ， 10$ 型について終価の美 を調べたところ，表20に示すごとく，12型の終価 と一致した回数30回中， 1 型 は 3 回，3型は 7 回，6型 5 回であつたが, 10 型は15回で,他の型よ り明らかに一致の回数が多かつた。これは10型と 12型が同じM抗原を有するとのLancefield ${ }^{17) ら ~}$ の知見々炤合して興味梁い。

（8）リウマチ团子との関連性の有無にかんす る椟討

リウマキ熱19例，リウマチ性心疾患11例，リウ マチ様関節炎28例，简炎24例につき，型抗体を RA testとの関連を檢討した結果，表21，22に示す ごとく，型の数とも，最高終価とも関連を認めな 
婊21. 型抗体の数々 RA test

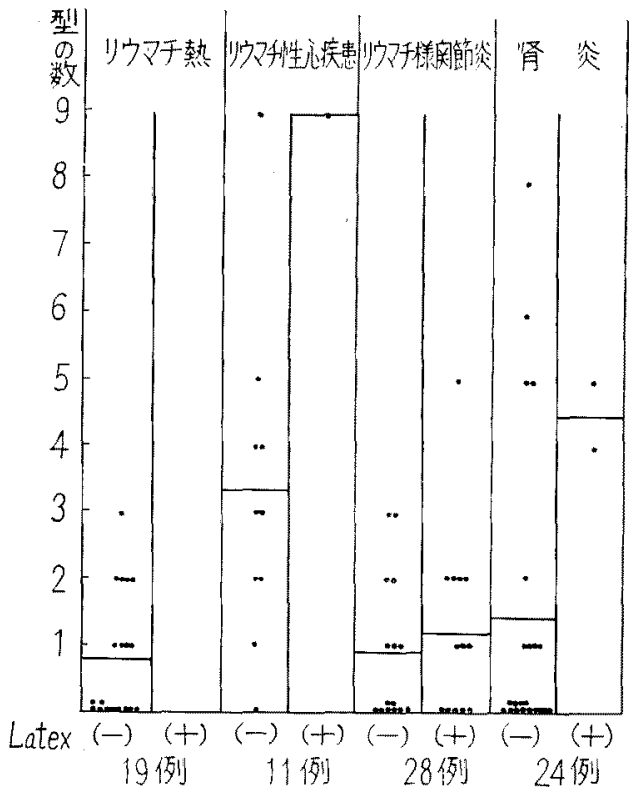

表22. 型抗体の最高箖值と RA test

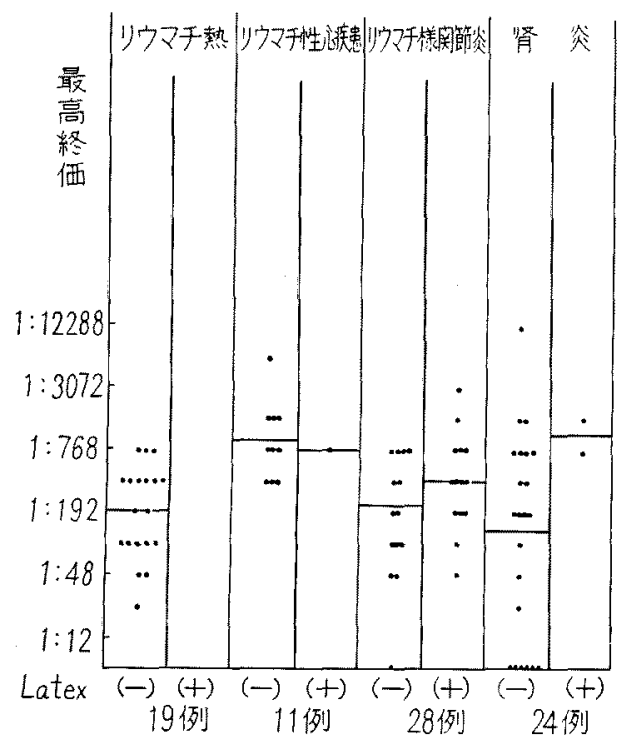

からな。

型抗体とRose区応との関係であるが，リウマチ 熱 9 例，リウマチ性心疾患18例，リウマチ稼関節 炎24例，腎炎21例㮔討した結果，表23，24に示 すごとく，型の数とも，最高終価とも関連を認め
表23. 型抗体の数とRose反応

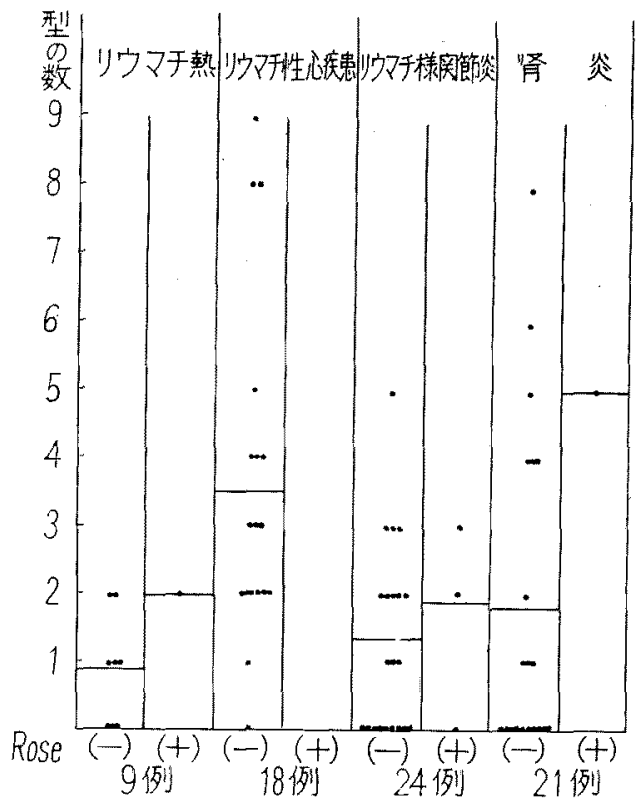

表24. 型抗体の最高終価とRose反応

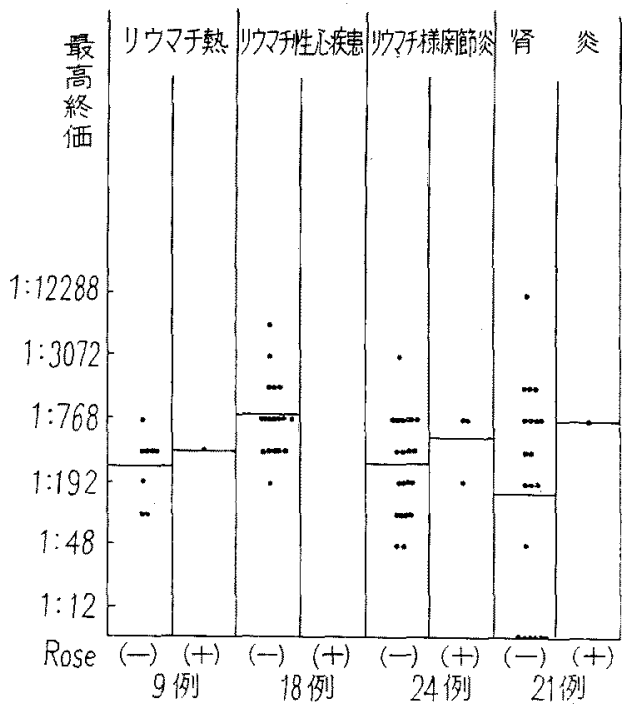

なかつた。

型抗体とF II testの関係であるが、リウマテ熱 10例，リウマチ性心疾患17例，リウマ斗美閔炎 13例，腎炎19例につき检討した結果，表25，26に 示すごとく，型の数とも，最高終価とも閜連を示 
表25. 型抗体の数とF II test

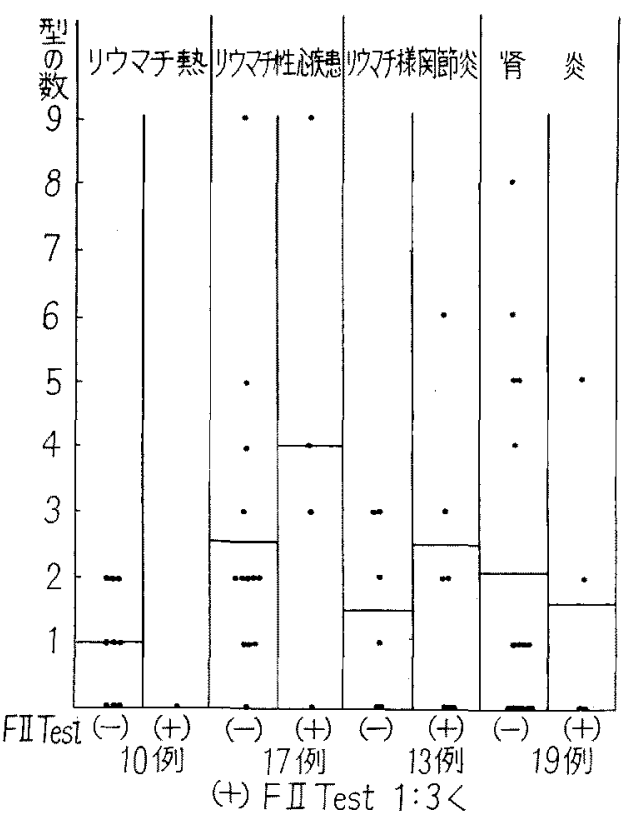

表26。型抗体の最高終価とF II test

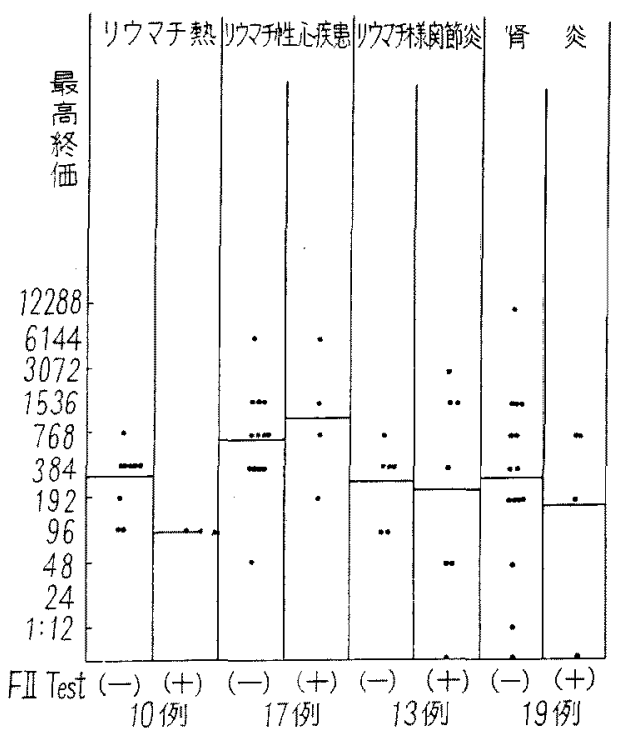

(+) FII Test 1:3<

さなかつた，次にリウマチ漛関節炎の患者血清 について，型抗体の最高終価とF II testの最高

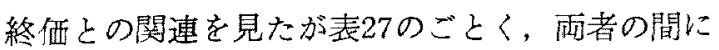
全く関係がなかつた。ささらに，ヒト血清とーグロブ
表27. 型抗体の最高終洒とF II testの最高終価 (りウマ千様関節炎)

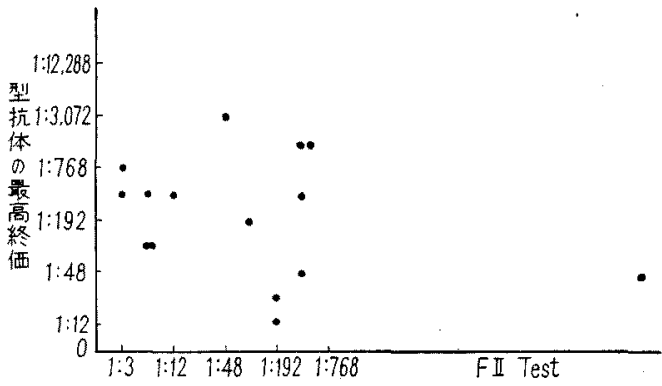

表28. 型抗体とF II testの交叉抑制試験（I） (高い終価の血清)

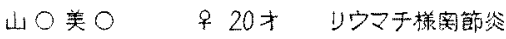

\begin{tabular}{|c|c|c|c|}
\hline 血球 & 抗原 & $1: 384$ & Control \\
\hline $0 T 6$ & $\begin{array}{l}A \\
B \\
C\end{array}$ & $\left\{\begin{array}{l}++++++ \pm--- \\
++++++ \pm--- \\
--------\end{array}\right.$ & $\begin{array}{l}- \\
- \\
-\end{array}$ \\
\hline OTY & $\begin{array}{l}A \\
B \\
C\end{array}$ & $\begin{array}{l}+++ \pm------ \\
-------- \\
+++ \pm----\ldots\end{array}$ & $\begin{array}{l}- \\
-\end{array}$ \\
\hline & $\begin{array}{l}A \\
B \\
C\end{array}$ & $\begin{array}{l}\text { B.S. }+1 \% \mathrm{R}-0 \\
0.25 \mathrm{mg} / \mathrm{cc} \gamma-g \text { lobulin } \\
\text { Typ } 6 \mathrm{M} \text { protein抗原葆 } 01: 50 \text { 液 } \\
\text { Latex }(+) \quad \text { Rose }(-) \quad \text { ASL- }\end{array}$ & 166 \\
\hline
\end{tabular}

型抗体とF II testの交㕛抑制試験（II） (低い終洒の血清)

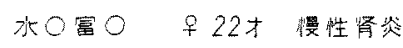

\begin{tabular}{|c|c|c|c|}
\hline 血球 & 抑制 & $1: 12$ & Control \\
\hline OT3 & $\begin{array}{l}A \\
B \\
C\end{array}$ & $\begin{array}{l}++++ \pm---- \\
++++ \pm---- \\
--------\end{array}$ & $\begin{array}{l}- \\
- \\
-\end{array}$ \\
\hline OTy & $\begin{array}{l}A \\
B \\
C\end{array}$ & $\begin{array}{l}++++ \pm---- \\
----:--- \\
++++ \pm----\end{array}$ & $\begin{array}{l}- \\
- \\
-\end{array}$ \\
\hline & B: & $\begin{array}{l}\text { B.S. }+1 \% \mathrm{R}-0 \\
0.25 \mathrm{mg} / \mathrm{cc} \gamma-\text { globulin } \\
\text { lype } 3 \mathrm{M} \text {-protein 抗原液 } 01\end{array}$ & \\
\hline
\end{tabular}

リンと溶連菌抽出抗原液による交叉抑制試騃を行 なつた。表28はリウマチ様関節焱の患者で 6 型に 高い終価の型抗体について行なつたのであるが， ケグロブリンと6型抗原液によつて，それぞれ特 異的に抑制されている。表29は3型に低い終価を 


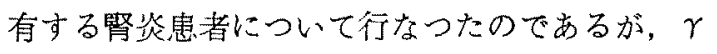
グロブリンと 3 型抗原液によつて，それでれ特異 的に抑制されている. 以上の結果より，本凝集区 応がリウマチ因子とは無関係に反志を示している 当の上思われる。

\section{IV. 考 案}

溶連菌型特異抗体を証明する方法として, 初め に, Denny 18j19)功Boydenの感作多ンニン陵赤血 球凝集反応を試みたのであるが，動物血清につい ては成功したが，患者血清については非特異的反 応のため不成功に終つた。これはDenny 緩㣫液 を使用せず，したがつて，タンニン酸処置血球凝 集反広のpHによる終洒の変動についての考虑がな されなかつたことにも一因㔔あると思われる。ま た，血球濃度も2\%の薄いものを用いているが， この濃度では，溶連菌酸抽出抗原を感作した場 合，管底像が開き易い状態となり，本来なら，目 のつぶれるはずの詨脂すら開いて輪状となり，陽 性と陰性の区別がつきにくくなる，また，溶連菌 の抗原は，他の抗原に比して血球凝集にたいする 過敏性が強く，酸で処理されているため，なおさ らのことである、しかし、このことは菌の型にも 関係し，非常に不安定な菌株のあるこを経験し た. 酸抽出抗原 ${ }^{18}$ ) は proteinの他に，未知の蛋 白を含む粗抗原であるため，血清中には，型特異抗 体以外に溶連菌体の蛋白質性抗原にたいする抗体 が存在する可能性があると思われる。すなわち， 前者を主抗原とすれば，後者屽副抗原で，かつ， 共通抗原の役割を果たすとも考えられる。本凝集 反応の低い終洒すなわち，1：192倍以下で認め られた交叉区応加々思和るるのは，二の共通抗 原によるものか子知れない，あるいは，残存した 菌液による血球凝集反応の抑制加も知れないが， 少なくとも 1 ：384倍以上の高い終洒を有した埸 合は，菌液による吸収試験によつても，著しい終 洒の低下はなく，型特異抗体によるものと考えら れた，抗原をさらに精製するなら，この交文反応 をより少なくすることができるかとも思われる が, 今後の問題であり, 現在の段階では, 粗抗原
液を用いても，1：384倍以上の高い終価を問題 とするなら，充分用いうる，また，各菌型の抗原 量については菌株，培養条件等によつても相違が あり，感染を受けても，抗体洒の上昇し難い菌型 もあるようである。最近, Quinn ${ }^{20)}$ 女鶏赤血球を タンニン酸で処置し溶連菌抗原を感作し，患者血 清について型特異抗体を観察しうると述べてい る、しかしこの方法はヒト血清中の鷄血球にた いする異好性抗体安矮血球て吸収する必要があ り，ヒトO型血球を用いる本法は、この必要がな くより簡單である。臨床的検討の結果については 第2編において報告する。

\section{V. 結 論}

Boydenの感作タンニン 酸赤血球凝集反応の改 良法を初的て溶連菌感染症に応用し，菌液による 吸収試験，抗原液に上る抑制反応，Bactericidal test との比較, 咽頭培養菌型との比較, 抗原のトリ プシン処置等種々な方法で，その型特異性を証明 した。また，反応の再現性，多価抗原に上る感作， 抗原濃度，艾叉区応，リウマチ因子との関連性の 有無等においても検討し, 若干の考案を試みた。

\section{文 献}

1) Lancefield, R.C.: The antigenic complex of streptococcus hemolyticus, J. exp. Med., $47: 91$, 469, 481, 843.-2) Diefendorf, H.W.: A method for detecting in human serum protective bodies against hemolytic streptococci. Proc. Soc. exp. Biol., 48: 56, 1941. - 3) Rantz, L.A., Kirby, W.M. and Jacobs, A.H.: Griffith type aggluti$\mathrm{nin}$ and antistreptolysin titers in normal men and in acute infections, J. clin. Invest., $32: 411$, 1943. - 4) Swift, H.F. and Hodge, B.E.: Typespecific anti $M$ precipitions in rheumatic and non-rheumatic patients with hemolytic streptococcal infections, Proc. Soc. exper. Biol., 34:849, 1936. - 5) Todd, E.W.: A method of measuring the increase or decrease of the population of hemolytic streptococci, Brit. J. exp. Path. 8: 1,1927. - - 6) 能谷直秀: 感作タンニン酸血球凝集 ならびに抑制反応の研究, 日新医学, $47(6)$ : 396, 1960. - 7) Boyden, S.V.: The absorption of proteins on erythrocytes treated with tannic acid and subsequent hemagglutination by antiprotein sera, J. exp. Med., $93: 107,1951 .-8$ ) 
Todd, E.W. and Hewitt, L.F.: Dubos' Bacterial and Mycotic Infection of Man. 1st Ed. p. 286, 1948. 一9) 草間秀夫：溶血机えさ球菌の血清学的 分類の手技について, Modern Media, 4(5): 166，1958. 一-10) 触弓之助：猩紅熱を中心とした 溶連菌について その3) 各地上り分与された溶速 菌の菌型，第30回日伝学会総会一般演説要旨，30 : 204, 1956. 一 11) 中沢秀夫 : 溶連菌の疫学的研 究, 日层会誌, $34(1): 63,1960$. - 12) 篗马 之助，小林健三：猩紅綮と溶連菌の群及び型， 31 ( 5 ) : 346, 1957. -13) Conroy, E. and Updyk, E.L.: The use of fraction of mechanically disrupted cells for production of group A streptococcus typing an tisera, Science, $119: 69$, 1954. -14) Lancefield, R.C.: A micro precipitin-technic for classifing hemolytic streptococci and improved method for producing antisera, Proc, Soc. exp. Biol., 38 : 473, 1938,-15) Rant $z_{2}$ L.A. et al.: A modifi cation of the technic for determination of the antistreptolysin titer, Proc. Soc. exp. Biol., 59 : 22, 1945. -16) Lancefield, R.C.: Persistence of type-specific antibodies in man following infection with group a streptococci, J. exp. Med., 110:271, 1959. -17) Watson, R.F, and Lancefield, R.C.: Studies on the antigen composition of group A hemolytic streptococci. III Types with serologically identical $\mathrm{M}$ but distinct $\mathrm{T}$ antigens: Type 10 and 12, J. exp. Med., $79: 89$, 1944. - 18) Denny, F.W. and Thomas, L.: The demonstration of type specific streptococcal antibody by a hema, gglutination technique employing tannic acid, J. clin. Invest., $32: 1085,1953 .-19)$ Denny, F.W., Perry, W.D. and Wannamaker L.W.: J. clin. Invest., $36: 1092$, 1957. - 20) Quinn, R.W.: Type specific anti $M$ antibodies against streptococcal pyogenes humanserum, 第 8 回国 際微生物学会，モントリオール,1962年8月。 